\title{
Correction to: Bee pollen and propolis improve neuroinflammation and dysbiosis induced by propionic acid, a short chain fatty acid in a rodent model of autism
}

Kawther Aabed ${ }^{1}$, Ramesa Shafi Bhat ${ }^{2}$, Abeer Al-Dbass ${ }^{2}$, Nadine Moubayed ${ }^{3}$, Norah Algahtani ${ }^{4}$, Nada M. Merghani ${ }^{4}$, Azizah Alanazi ${ }^{5}$, Naima Zayed ${ }^{6}$ and Afaf El-Ansary ${ }^{4,6^{*}}$

Correction to: Lipids Health Dis 18, 200 (2019)

https://doi.org/10.1186/s12944-019-1150-0

Following publication of the original article [1], it was noticed that the published version of this article has typographical error in the Acknowledgements and Funding Declarations. Specifically, the "Princess Nora Bint Abdulrahman University" should be "Princess Nourah Bint Abdulrahman University". The original article has been corrected.

\footnotetext{
Author details

${ }^{1}$ Biology Department, College of Science, Princess Nourah Bint AbdulrahmanUniversity, Riyadh, Saudi Arabia. ${ }^{2}$ Biochemistry Department, College ofSciences, King Saud University, Riyadh, Saudi Arabia. ${ }^{3}$ Biology Department,College of Sciences, King Saud University, Riyadh, Saudi Arabia. ${ }^{4}$ Centrallaboratory, Female Centre for Scientific and Medical Studies, King SaudUniversity, Riyadh, Saudi Arabia. ${ }^{5}$ Department of Cell Biology, King FaisalSpecialist Hospital and Research Centre, Riyadh, Saudi Arabia.

${ }^{6}$ TherapeuticChemistry Department, National Research Centre, Dokki, Cairo, Egypt.
}

Published online: 04 July 2021

\section{Reference}

1. Aabed K, Bhat RS, Al-Dbass A, et al. Bee pollen and propolis improve neuroinflammation and dysbiosis induced by propionic acid, a short chain fatty acid in a rodent model of autism. Lipids Health Dis. 2019;18:200 https://doi.org/10.1186/s12944-019-1150-0.

The original article can be found online at https://doi.org/10.1186/s12944019-1150-0.

* Correspondence: afafkelansary@gmail.com

${ }^{4}$ Centrallaboratory, Female Centre for Scientific and Medical Studies, King SaudUniversity, Riyadh, Saudi Arabia

${ }^{6}$ TherapeuticChemistry Department, National Research Centre, Dokki, Cairo, Egypt

Full list of author information is available at the end of the article

(c) The Author(s). 2021 Open Access This article is licensed under a Creative Commons Attribution 4.0 International License, which permits use, sharing, adaptation, distribution and reproduction in any medium or format, as long as you give appropriate credit to the original author(s) and the source, provide a link to the Creative Commons licence, and indicate if changes were made. The images or other third party material in this article are included in the article's Creative Commons licence, unless indicated otherwise in a credit line to the material. If material is not included in the article's Creative Commons licence and your intended use is not permitted by statutory regulation or exceeds the permitted use, you will need to obtain permission directly from the copyright holder. To view a copy of this licence, visit http://creativecommons.org/licenses/by/4.0/ The Creative Commons Public Domain Dedication waiver (http://creativecommons.org/publicdomain/zero/1.0/) applies to the data made available in this article, unless otherwise stated in a credit line to the data. 